\title{
Expression and possible role of fibroblast growth factor family members in porcine antral follicles during final maturation
}

\author{
Dieter Schams, Vera Steinberg, Martin Steffl ${ }^{1}$, Heinrich H D Meyer and Bajram Berisha \\ Physiology Weihenstephan, Technical University Munich, Weihenstephaner Berg 3, D-85350 Freising, Germany and \\ ${ }^{1}$ Anatomy and Physiology, University of Hohenheim, D-70593 Stuttgart, Germany \\ Correspondence should be addressed to B Berisha; Email: berisha@wzw.tum.de
}

\begin{abstract}
The aim of this study was to investigate the possible participation of fibroblast growth factor (FGF) family members (FGF1, FGF2 and FGF7 and their receptors) in porcine follicles (polyovulatory species) under special consideration for FGF2 during final growth. A classification of follicles was done by size and follicular fluid content of oestradiol-17 $\beta$, progesterone and prostaglandin F2 $\alpha$. The mRNA expression of examined factors was analysed by real-time PCR. The hormone concentration was estimated by enzyme immunoassay, protein characterisation by western blotting and localisation by immunohistochemistry. Follicle tissue separated in theca interna and granulosa cells was extracted and tested for mRNA of FGF1, FGF2, FGF7 and receptors (FGFR1IIIc, FGFRIIIb and FGFR2IIIC). Additionally, the mRNA expression of FSHR, LHR and aromatase cytochrome P450 for further characterisation of follicles was analysed. Significantly, higher FGF2 protein levels were measured in stroma when compared with total follicle or corpus luteum tissue. This result was confirmed by western blot with two strong bands. Immunological localisation of FGF2 only in stroma (fibroblasts) confirms the protein measurements. The results show a clear difference for FGF2 protein expression during final growth of follicles if monovulatory (bovine) and polyovulatory (porcine) species are compared. FGF2 protein in porcine ovary may be (due to localisation and concentration in stroma) important for support of angiogenesis of more follicles (polyovulatory species) and not of a single follicle like in cows.

Reproduction (2009) 138 141-149
\end{abstract}

\section{Introduction}

It is now well established in many species that locally produced growth factors have important modulatory and stimulatory roles in final follicular growth. The ovarian cycle is characterised by repeating patterns of cellular proliferation, differentiation and transformation that accompany follicular and luteal development. Tissue growth in the ovary (follicle or corpus luteum $(\mathrm{CL})$ ) depends upon the growth of new blood vessels and establishment of a functional blood supply (angiogenesis). Angiogenesis may play an important role in the selection process of follicles. Zeleznik et al. (1981) suggested that the selected follicles possess more elaborate microvasculature than other follicles. We concluded from studies in cow that vascular endothelial growth factor (VEGFA) and fibroblast growth factor 2 (FGF2) are involved in the proliferation of capillaries that accompany the selection of the preovulatory follicle resulting in an increased supply of nutrients, precursors and hormones, and therefore supporting the growth of the dominant follicle (Berisha et al. 2000a, Yamashita et al. 2008).

The importance and possible role of FGFs in ovary is not so well documented. The FGFs belonging to a big family have a wide range of tissue and cell distribution
(Gospodarowicz et al. 1987). FGF1, FGF2 and FGF7 were demonstrated in the bovine ovary (Gospodarowicz et al. 1985, Schams et al. 1994, Parrott \& Skinner 1998, Sinowatz et al. 2006). The FGF receptor family (FGFR) includes four identified genes and numerous subtypes of alternatively spliced isoforms, particularly within the well-characterised FGFR1 and FGFR2 types. Differential responses follow from this diversity (Johnson \& Williams 1993, Stauber et al. 2000). FGF2 has been identified as a potential regulator of ovarian function (Gospodarowicz et al. 1985, Schams et al. 1994). FGF2 promotes twice as potent angiogenesis in three-dimensional in vitro models compared with VEGF (Pepper et al. 1992). Results suggest that FGF2 and VEGFA have a potent synergistic effect on the induction of angiogenesis in vitro. In bovine endothelial cell culture, FGF2 in the medium upregulated the expression of both VEGF receptors (FLT1 and KDR; Gabler et al. 2004).

The distinct immunohistochemical localisation of FGF2 in selected bovine dominant follicles in cytoplasm of capillary endothelial cells (Berisha et al. 2000a, 2006a) suggests an important role of FGF2 for the selection process in monovulatory bovine species. If this hypothesis is correct, we should see differences in FGF2 expression and localisation in polyovulatory species. The aim of the 
present study was therefore to evaluate the possible participation of FGF family members (FGF1, FGF2 and FGF7) under special consideration of FGF2 and their receptor variants (FGFR1IIIc, FGFR2IIIb and FGFR2IIIc) during final follicle maturation in porcine ovary as a polyovulatory species. The results should be compared and discussed with those in the monovulatory bovine species.

\section{Results}

\section{Characterisation of tested follicular groups}

The average concentrations of oestradiol-17 $\beta\left(E_{2}\right)$, progesterone (P4) and prostaglandin $\mathrm{F} 2 \alpha(\mathrm{PGF} 2 \alpha)$ in follicular fluid (FF) for the different groups are shown in Table 1. Concentration levels for both steroids in FF $\left(E_{2}\right.$ and $\left.\mathrm{P} 4\right)$ increased significantly in large follicles ( $>7 \mathrm{~mm}$ ), followed by sharp decrease of $E_{2}$ in periovulatory follicles or remaining high levels of P4 in periovulatory follicles. By contrast, PGF2 $\alpha$ values are very low in antral follicles followed by a dramatic increase in periovulatory follicles.

The mRNA expression for FSHR, LHR and aromatase cytochrome P450 (CYP19A1) in separated theca interna (TI) and granulosa cells (GC) are presented in Fig. 1. FSHR showed in GC a relatively constant expression. By contrast, the $L H R$ mRNA expression in GC and TI increased significantly from small to large follicles followed by a sharp decrease in the periovulatory group. The CYP19A1 expression profile in GC and $\mathrm{TI}$ was comparable with that of the $L H R$.

\section{Expression of mRNA for FGF1, FGF2 and FGF7 and FGF receptors}

The mRNA expression in separated follicle tissue (Fig. 2) for FGF1, FGF2 and FGF7 was relatively similar in $\mathrm{TI}$ and GC tissue with few significant changes for FGF1 in $\mathrm{TI}$ and FGF2 in $\mathrm{TI}$ and GC. The expression intensity was generally higher for FGF2, if compared with FGF1 and FGF7. The mRNA expression for the receptors FGFR1IIIC, FGFR2IIIb and FGFR2IIIC in separated follicular tissue is given in Fig. 3. The FGFR1IIIC expression profiles in $\mathrm{TI}$ and GC were comparable and showed a decrease in large follicles followed by an increase in the periovulatory group (Fig. 3).
The FGFR2IIIC expression in TI and GC was relative constant. Only FGFR2IIIb showed an upregulation in TI for large and periovulatory groups (Fig. 3).

\section{FGF2 protein concentration and characterisation}

Follicle tissue (after removal of FF), stroma and CL tissue were homogenised, extracted and the supernatant was tested for FGF2 by a commercial enzyme immunoassay (EIA). The results are shown in Fig. 4a. Significantly, higher FGF2 protein concentrations were measured in stroma if compared with total follicle or CL tissue. This result was confirmed by semi-quantitative western blot as demonstrated in Fig. 4b. A weak $18 \mathrm{kDa}$ band was seen in follicle tissue after extraction comparable with the bovine FGF2 standard. Two much stronger bands were seen in stroma tissue in all three pools tested corresponding to 18 and $22 \mathrm{kDa}$.

\section{FGF2 protein localisation}

The quantitative and semi-quantitative differences between FGF2 content in ovarian tissue were further confirmed by immunohistological localisation of FGF2 in tissue (see Fig. 5). In paraffin sections of porcine ovaries, immunohistochemical procedure revealed celltype-specific staining of FGF2. Strong immunoreaction for FGF2 is selectively found in numerous stromal cells around and between different follicle categories obtained from different follicular phases ( $a$ and $c$ ). At the cellular level, the strong immunostaining is restricted to the nucleus of fibroblasts (b and d) with weak staining of cytoplasm. No staining can be observed in theca or granulosa cells of large (a) and small (c and d) follicles, or in endothelial cells of capillaries or larger blood vessels in porcine ovarian tissue (e). The negative control section on which the primary antiserum was not applied does not show any immunoreactivity (f).

\section{Discussion}

The collection of our follicles from slaughterhouse material does not allow determination of the exact stage of follicular development. The classification of our follicles according to size, and the $\mathrm{P} 4, \mathrm{E}_{2}$ and PGF $2 \alpha$ content in FF and expression of mRNA for FSHR,

Table 1 Follicle diameter $(\mathrm{mm})$ and follicle fluid (FF) concentration of oestradiol- $17 \beta\left(E_{2}\right)$, progesterone and PGF $2 \alpha$ (mean \pm s.E.M.) for the examined porcine antral follicle groups ( $n=6-10$ follicle/group) from $n=5$ sows.

\begin{tabular}{lccr}
\hline & & \multicolumn{3}{c}{ Follicular fluid concentration $(\mathrm{ng} / \mathrm{ml})$} \\
\cline { 2 - 4 } Follicle group & $\mathrm{E}_{2}$ & Progesterone & PGF2 $\alpha$ \\
\hline Diameter $(\mathrm{mm})$ & $12.1 \pm 1.6^{\mathrm{a}}$ & $108.0 \pm 8.9^{\mathrm{a}}$ & $121.4 \pm 22.1^{\mathrm{a}}$ \\
$2-3 \mathrm{~mm}$ & $44.8 \pm 7.9^{\mathrm{a}}$ & $88.1 \pm 11.6^{\mathrm{a}}$ & $234.6 \pm 107.4^{\mathrm{a}}$ \\
$4-6 \mathrm{~mm}$ & $220.2 \pm 29.9^{\mathrm{b}}$ & $364.0 \pm 67.8^{\mathrm{b}}$ & $425.5 \pm 124.1^{\mathrm{a}}$ \\
$>7 \mathrm{~mm}$ & $27.1 \pm 5.3^{\mathrm{a}}$ & $281.6 \pm 2.8^{\mathrm{b}}$ & $13782.0 \pm 2851.6^{\mathrm{b}}$ \\
Periovulatory & & & 7820 \\
\hline
\end{tabular}

Different superscripts denote statistically different values $(P<0.05)$. 

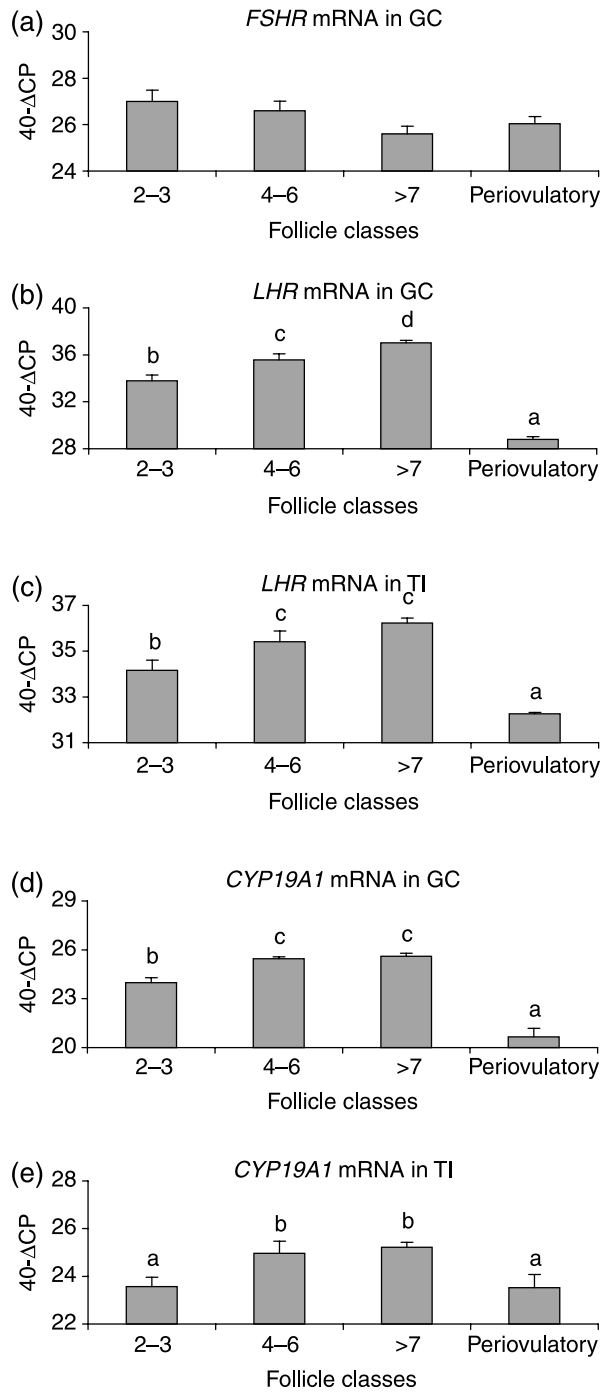

Figure 1 Expression of mRNA for (a) FSHR in GC, (b) LHR in GC, (c) LHR in TI, (d) CYP19A1 in GC and (e) CYP19A1 in TI, in porcine antral follicle groups. The changes in mRNA expression of examined factors were assayed by normalisation to the $U B Q$ internal control. In order to obtain the CP (crossing point) difference, the data were analysed using the $\Delta \Delta C P$ method described previously by Livak \& Schmittgen (2001). Thereby, $\Delta$ CP was not subtracted from a control group, but from the value 40 , so that a high $40-\Delta C P$ value indicated a high-gene expression level and vice versa. Results are presented as mean \pm s.E.M. $(n=5-6$ follicles/class). Different superscripts denote statistically different values $(P<0.05)$.

LHR and CYP19A1 support our classification system and allow some conclusions in comparison with data from the literature. Our follicle diameter and steroid levels in FF agree quite well with recently published data with well-defined porcine material (Corbin et al. 2003) or earlier data (Ainsworth et al. 1980, Babalola \& Shapiro 1988, Grant et al. 1989). The periovulatory group is defined and selected by the very high ascent of PGF2 $\alpha$ level in FF. The level increases in such a way a few hours before ovulation,
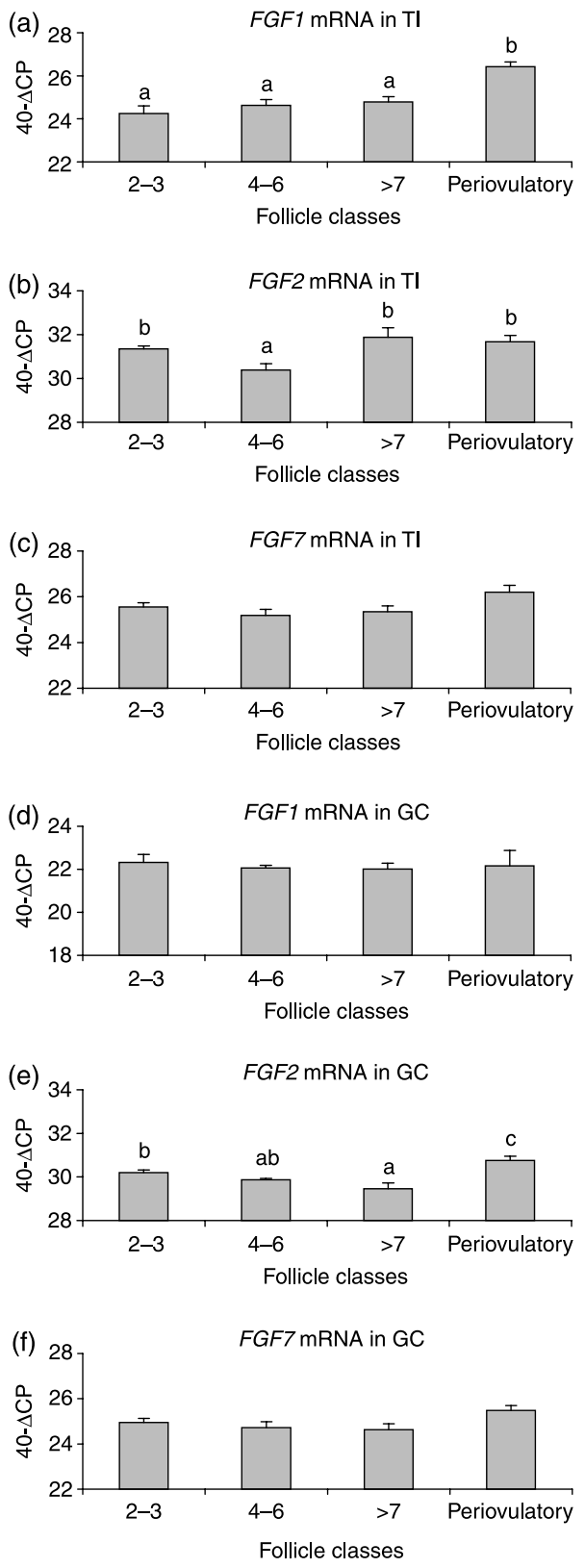

Figure 2 Expression of mRNA in TI for (a) FGF1, (b) FGF2, (c) FGF7 or in GC for (d) FGF1, (e) FGF2, (f) FGF7. The changes in mRNA expression of examined factors were assayed by normalisation to the $U B Q$ internal control. Results are presented as mean \pm S.E.M. $(n=5-6$ follicles/class). Different superscripts denote statistically different values $(P<0.05)$.

as shown for the pig (Hunter \& Poyser 1985) and cow (Berisha et al. 2006a). The typical descent of CYP19A1 and $L H R$ mRNA expression confirms further our classification.

In contrast with the cow (Berisha et al. 2000a), the FSHR mRNA expression trended to decrease during porcine follicle maturation. This agrees with findings by Cardenas \& Pope (2002). The LHR mRNA shows already high expression in small follicles in both compartments 

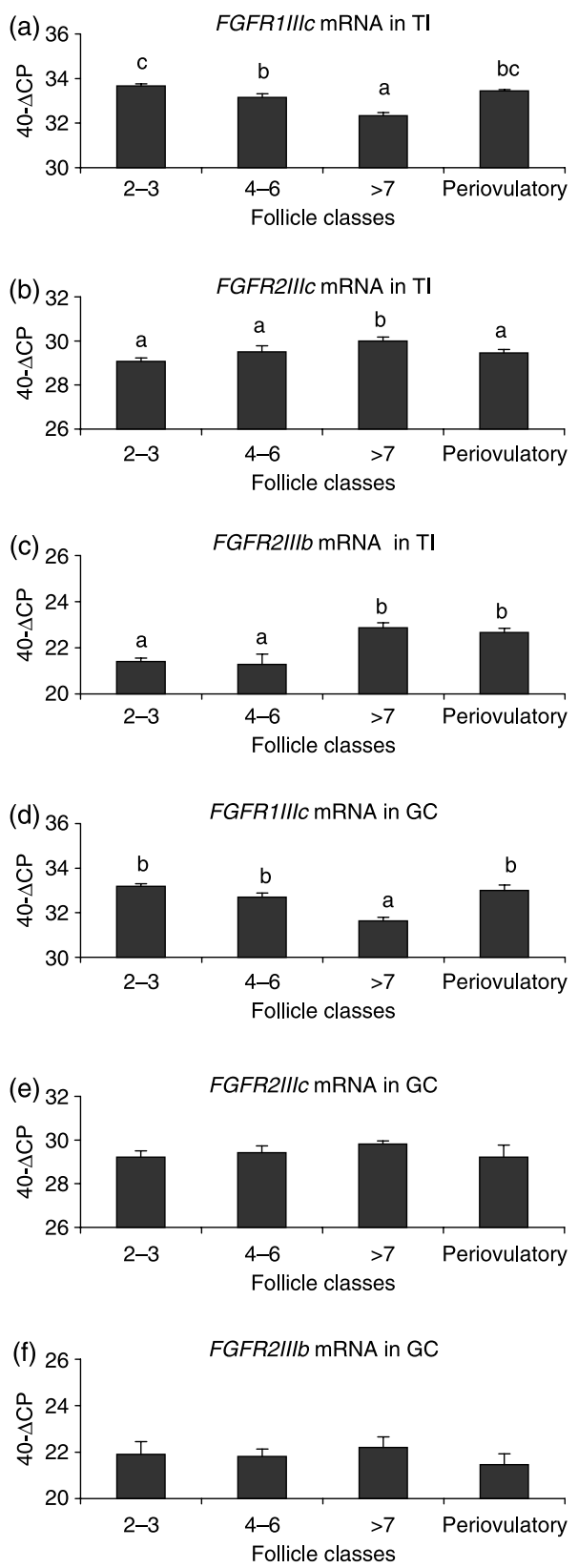

Figure 3 Expression of mRNA in porcine follicle tissue (TI or GC): in $\mathrm{TI}$, (a) FGFR1IIIC, (b) FGFR2IIIc and (c) FGFR2IIIb; in GC, (d) FGFR1IIIC, (e) FGFR2IIIC and (f) FGFR2IIIb. The changes in mRNA expression of examined factors were assayed by normalisation to the UBQ internal control. Results are presented as mean \pm S.E.M. $(n=5-6$ follicles/class). Different superscripts denote statistically different values $(P<0.05)$.

(TI and GC), increases in large follicles and decreases after $\mathrm{LH}$ surge. An increase of $L H R$ in GC in large follicles was also observed in pigs (Liu et al. 1998) and cows (Berisha et al. 2000a). The mRNA expression pattern for CYP19A1 also agrees with reports in the literature (Ainsworth et al. 1990, Guthrie et al. 1994). Atretic follicles show a low CYP19A1 mRNA expression (Garrett \& Guthrie 1997). Our data for CYP19A1 expression and $E_{2}$ concentration suggest no atretic follicles in our groups. The clear mRNA expression and localisation of protein for FGF1, FGF2 and FGF7 in the bovine ovary suggest an important role for local ovarian regulation (Parrott \& Skinner 1998, Berisha et al. 2004, Schams \& Berisha 2004). In the present study, we also demonstrated mRNA expression for these factors (ligand and receptors) in the porcine ovary. The possible role of FGF1 in the ovary is still not clear. Significant regulatory changes of FGF1 expression during final follicle growth were observed in porcine (Fig. 2) or bovine tissue (Berisha et al. 2004, 2006b). The immunoreactive localisation of FGF1 in smooth muscles of the blood vessels and GCs in cows (Berisha et al. 2004) suggests survival function. Due to the mRNA expression in porcine $\mathrm{TI}$ and GC, comparable actions can be assumed.

The unregulated mRNA expression for FGF7 in $\mathrm{TI}$ and GC in all groups agrees with data from cows (Berisha et al. 2004). In this species, a significant increase in expression was seen only during LH surge and in early CL. The protein is marked localised in the theca, the basal layers of the GC and the smooth muscle cells of blood vessels. FGF7 is distinguished from most other FGF family members by its strict paracrine mode of action. As suggested by Parrott et al. (1994) and Parrott \& Skinner (1998), FGF7 is expressed and protein secreted to the GC and may

$$
\text { (a) FGF2 peptide concentration (EIA) }
$$

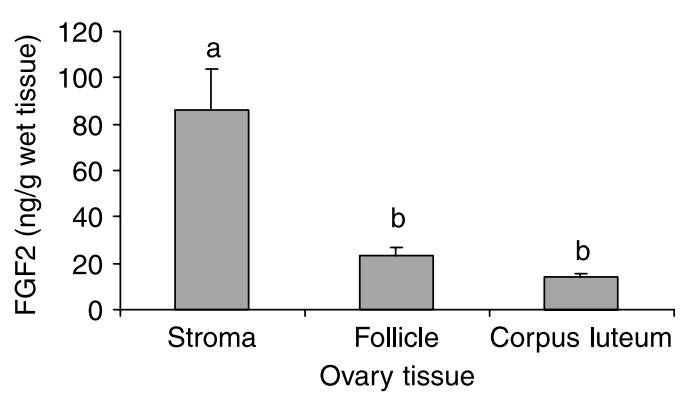

(b) FGF2 peptide characterisation (Western blot)

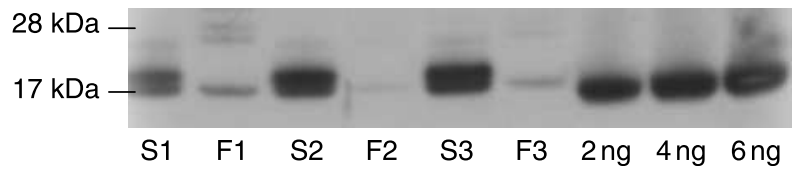

Figure 4 (a) Tissue concentration of FGF2 protein (ng/g wet weight) in different porcine ovary tissue (follicle, stroma and $\mathrm{CL}$ ) as measured by EIA. Follicle pools, stroma and CL tissue $(n=5)$ were obtained from five sows per group. Results are presented as mean \pm S.E.M. Different superscripts denote statistically different values $(P<0.05)$. (b) Western-blot protein characterisation of FGF2 in different ovary tissue (stroma and follicle). Stroma tissue (S) and follicle tissue (F) from early (S1 and F1), mid (S2 and F2) and late (S3 and F3) follicle phases ( $n=3$ tissue samples/different animals). The standards of rbFGF2 protein are 2, 4 and $6 \mathrm{ng}$. The position of molecular mass markers is indicated on the left. 

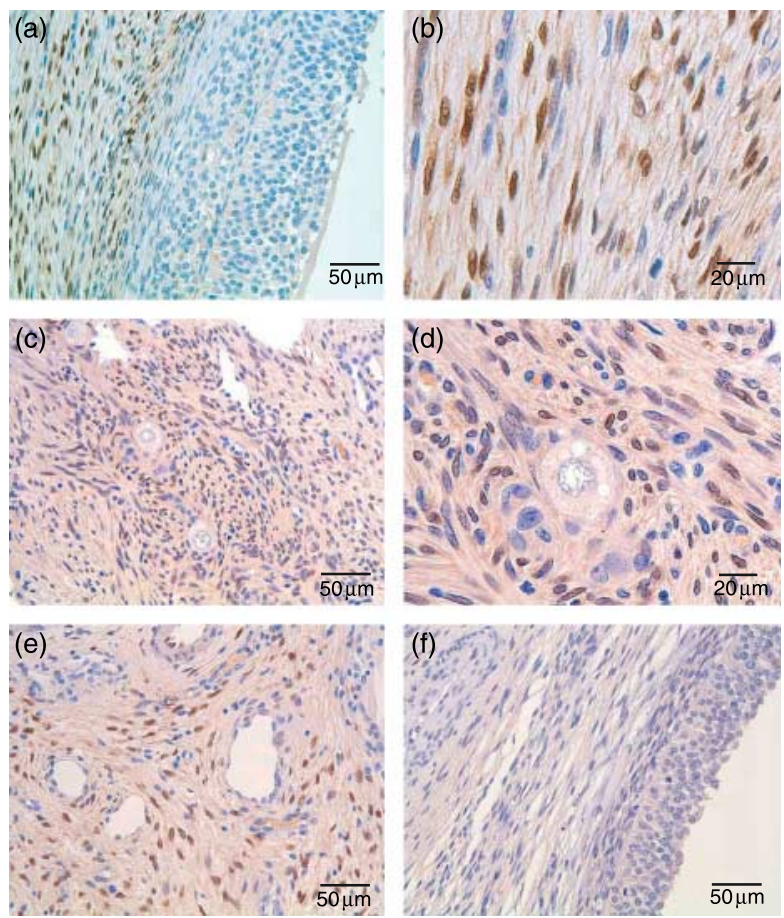

Figure 5 Immunohistochemical localisation of FGF2 in porcine ovary. (a) Stroma tissue shows a strong immunolocalisation of FGF2. Very weak staining or no signal of FGF2 was detected in theca externa, $\mathrm{TI}$ and GC of the porcine ovary. (b) Nuclei of fibroblasts in stroma show strong staining and weaker staining in cytoplasm. (c and d) Again shows only clear staining in stroma but not in primary follicles. (e) Endothelial cells of blood vessels are also negative for FGF2. (f) Negative control.

stimulate proliferation of GC. We have not tested the localisation in the pig. But the significant higher expression of FGFR2IIIb in porcine TI of large follicles and periovulatory follicles may suggest also direct effects on theca cells.

But our main interest for this study was the FGF2 mRNA expression and protein profile in porcine follicles (polyovulatory species) and the comparison with bovine (monovulatory) species. FGF2 is a heparin-binding growth factor, which occurs in several isoforms resulting from alternative initiations of translation: a $18 \mathrm{kDa}$ cytoplasmic isoform and four larger molecular mass nuclear isoforms (22, 22.5, 24, and $34 \mathrm{kDa}$ respectively). Although devoid of a signal peptide, it could be secreted under certain circumstances. FGF2 upregulates the mRNA expression of FLT4 (Pepper \& Mandriota 1998), FLT1 and KDR (Gabler et al. 2004), and amplifies herewith the angiogenic property of VEGFA. The mRNA expression for FGF2 is comparably expressed in TI and GC. This is in contrast with bovine follicles (Berisha et al. 2000a), which show a strong upregulation of mRNA for ligand and receptor in TI of dominant follicles. The GC compartment shows only a weak (unregulated) expression.
Very exciting is the FGF2 protein concentration and localisation in porcine ovary demonstrating clear differences between mRNA expression and protein translation. The negative immunostaining for FGF2 in porcine follicles does not exclude some protein in follicles due to the less sensitive technique of immunohistochemistry. A weak band for FGF2 is seen in follicle by western-blot technique.

But nevertheless, the strong staining for FGF2 in fibroblasts of stroma tissue and higher stroma tissue concentrations when compared with follicle extracts suggest different regulatory mechanisms of porcine FGF2 on follicle growth and maturation if compared with the bovine. FGF2 mainly localised in stroma may act in different ways: i) autocrine-intracrine regulation of fibroblast by stimulating unknown factors acting on follicular growth, ii) paracrine effects on theca tissue (endothelial cells) of follicles and iii) FGF2 is constitutively required for stromal function or general ovarian angiogenesis. FGF2 secreted from fibroblasts may affect more follicles at the same time and stimulate angiogenesis, in contrast to the single bovine-dominant follicle. In contrast to the bovine (Seghezzi et al. 1988) FGF2 may stimulate VEGFA and therefore angiogenesis in porcine follicles by a paracrine mechanism. Very interesting is the demonstration of a strong second band $(22 \mathrm{kDa})$. This protein may be responsible for autocrine-intracrine function. Nuclear translocation of the growth factor is required for the induction of DNA synthesis (Imamura et al. 1990, Wiedlocha et al. 1996).

In conclusion, we have shown a distinct localisation of FGF2 between the single bovine-dominant follicle and the group of preovulatory porcine follicles. FGF2 in porcine ovary may be important for the growth of more follicles due to the localisation and concentration difference between stroma and follicle tissue.

\section{Materials and Methods}

\section{Collection, classification and preparation of follicles and $C L$}

Entire reproductive tracts from sows were collected at a local slaughterhouse within 10-20 min after slaughter and were transported on ice to the laboratory. The stage of the oestrous cycle was defined by macroscopic observation of the ovaries (colour, consistency, CL stage, number and size of follicles) and the uterus (colour, consistency and mucus; Leiser et al. 1988). Only follicles that appeared healthy (i.e. well vascularised and having transparent follicular wall and fluid) were used. For the periovulatory group, follicles were collected only after $\mathrm{CL}$ regression with signs of mucus production in the uterus and cervix.

Follicles were dissected from the ovary for RNA and protein extraction. The surrounding tissue (theca externa) was removed with forceps under a stereomicroscope. After aspiration of FF, the follicles were bisected and their inside wall was scraped 
intensively and flushed with Ringer's solution several times (Fresenius, Wendel, Germany) to remove the GC. The GC in the $\mathrm{FF}$ as well as in the flushing solution were centrifuged at $2000 \mathrm{~g}$ for $10 \mathrm{~min}$ at $4{ }^{\circ} \mathrm{C}$. The $\mathrm{TI}$ tissue and GC pellet were snap frozen in liquid nitrogen and stored at $-80{ }^{\circ} \mathrm{C}$ until RNA isolation. For follicle FGF2 tissue extraction, after aspiration of $\mathrm{FF}$, total follicle tissue was stored at $-80{ }^{\circ} \mathrm{C}$. The FF was stored at $-20{ }^{\circ} \mathrm{C}$ until determination of $\mathrm{P} 4, \mathrm{E}_{2}$ and PGF2 $\alpha$.

\section{Experiment 1}

Stroma tissue from different pieces of the ovary (follicle free), whole antral follicle and $\mathrm{CL}$ tissue was collected for comparison of FGF2 protein determination. The follicles were classified according to the $\mathrm{E}_{2}, \mathrm{P} 4$ and PGF2 $\alpha$ content in FF. The corresponding size of follicles was in the range of $2-3 \mathrm{~mm}$ (early follicle phase), 4-6 mm (mid follicle phase) and $>7 \mathrm{~mm}$ (late follicle phase).

\section{Experiment 2}

Antral follicles were divided into four groups according to the $E_{2}$, P4 and PGF2 $\alpha$ FF content and follicle diameter (Table 1). Separation of $\mathrm{TI}$ and GC compartments was obtained from following follicle groups: $2-3 \mathrm{~mm}, 4-6 \mathrm{~mm},>7 \mathrm{~mm}$ and periovulatory. For further characterisation of the follicle classes, mRNA expression was determined for the FSHR in GC and CYP19A1 and LHR in TI and GC.

\section{Hormone determinations in FF}

The concentrations of $\mathrm{P} 4$ and $\mathrm{E}_{2}$ were determined directly in the FF with an EIA using the second antibody technique (Meyer et al. 1990, Acosta et al. 1999). The effective dose for $50 \%$ inhibition (ED50) of the assay was $6 \mathrm{ng} / \mathrm{ml}$ for P4 and $3.5 \mathrm{pg} / \mathrm{ml}$ for $E_{2}$. The $F F$ was diluted accordingly. The intra-assay coefficient of variation (CV) values was $4.5 \%$ (P4) and $6.6 \%\left(\mathrm{E}_{2}\right)$ and the inter-assay $\mathrm{CV}$ values $8.7 \%(\mathrm{P} 4)$ and $9.4 \%$ $\left(E_{2}\right)$ respectively.

The EIA for PGF2 $\alpha$ (Acosta et al. 1999) was evaluated in different dilutions directly in FF without extraction. The standard curve for PGF2 $\alpha$ ranged from 0.6 to $700 \mathrm{pg} / \mathrm{ml}$, and the ED50 of the assay was 300-400 pg/ml. The intra and interassay CV values were 8 and $14 \%$ respectively.

\section{Tissue extraction}

One hundred milligrams of follicle (pool from 6 follicles), CL and stroma tissue was transferred into ten volumes of PBS (1 ml) containing one complete mini tablet of BSA (Boehringer, Mannheim, Germany). This tablet contains both reversible and irreversible protease inhibitors, and inhibits a broad spectrum of serine-, cysteine- and metallo-proteases. The tissue samples were homogenised using the FastPrep-System (BIO101, Carlsbad, CA, USA) with $0.8 \mathrm{~g}$ of Matrix Green ceramic beads at $6 \mathrm{~m} / \mathrm{s}$ for $40 \mathrm{~s}$ until the material was pulverised. After centrifugation for $10 \mathrm{~min}$ at $3500 \mathrm{~g}$, the total protein content in the supernatant was determined by a BCA test (Sigma-Aldrich Company).

\section{Isolation of RNA}

Total RNA was prepared from follicle and CL tissue according to Chomczynski \& Sacchi (1987) with TriPure isolation reagent (Roche Diagnostics) as described earlier in detail (Berisha et al. 2000b). Possible DNA contaminations were eliminated by an additional DNase digestion according to the manufacture's protocol (Promega). Total RNA was finally purified using Nucleospin RNA II (Macherey \& Nagel, Düren, Germany) with the concentration and purity being determined spectroscopically at an absorbance of $260 \mathrm{~nm}$ using a Biophotometer (Eppendorf, Hamburg, Germany). Aliquots were subjected to $1 \%$ denaturing agarose gel electrophoresis and ethidium bromide staining to verify the quantity and quality of total RNA.

\section{RNA RT and real-time PCR}

Constant amounts of $1 \mu \mathrm{g}$ of total RNA were reverse transcribed to cDNA using the following master mix: $26 \mu \mathrm{l}$ RNase-free water, $12 \mu \mathrm{l} 5 \times$ buffer (Promega), $3 \mu \mathrm{l}$ Random Primers $(50 \mu \mathrm{M}$; Invitrogen), $3 \mu \mathrm{l}$ dNTPs (10 mM; Fermentas, St Leon-Rot, Germany) and $200 \mathrm{U}$ of M-MLV Reverse Transcriptase (Promega) according to the manufacturer's instructions. Primer sequences are given in Table 2 .

A master mix of the following reaction components was prepared: $6.4 \mu \mathrm{l}$ water, $1.2 \mu \mathrm{IgCl}_{2}(4 \mathrm{mM}), 0.2 \mu \mathrm{l}$ forward primer $(0.2 \mu \mathrm{M}), 0.2 \mu \mathrm{l}$ reverse primer $(0.2 \mu \mathrm{M})$ and $1.0 \mu \mathrm{l}$ LightCycler Fast Start DNA Master SYBR Green I (Roche Diagnostics). The master mix ( $9 \mu \mathrm{l}$ ) was added to the strip tubes and $1 \mu \mathrm{l}$ PCR template containing 16.66 ng reverse-transcribed total RNA was added.

The following general real-time PCR protocol was employed for all investigated factors: denaturation for $10 \mathrm{~min}$ at $95^{\circ} \mathrm{C}$, 40 cycles of a three-segmented amplification and quantification program (denaturation for $10 \mathrm{~s}$ at $95^{\circ} \mathrm{C}$, annealing for $10 \mathrm{~s}$ at $60^{\circ} \mathrm{C}$, elongation for $15 \mathrm{~s}$ at $72{ }^{\circ} \mathrm{C}$ ), a melting step by slow heating from $60{ }^{\circ} \mathrm{C}$ to $99^{\circ} \mathrm{C}$ with a rate of $0.5^{\circ} \mathrm{C} / \mathrm{s}$ and continuous fluorescence measurement, and a final cooling down to $40{ }^{\circ} \mathrm{C}$. Data were analysed using Rotor-Gene 3000 software (version 5.03). The relative expressions of each target gene were calculated using the 'comparative quantification' method ('take-off' points). The increase in fluorescence signal recorded during the assay is proportional to the amount of DNA synthesised during each amplification cycle. Individual reactions are characterised by the cycle fraction at which fluorescence first rises above a defined background fluorescence, a parameter known as the threshold cycle or crossing point (CP). In order to obtain the CP difference, the data were analysed using the $\Delta \Delta$ (delta, delta) CP method described previously by Livak \& Schmittgen (2001). Thereby, $\Delta$ CP was not subtracted from a control group, but from the value 40 , so that a high ' $40-\Delta C \mathrm{P}^{\prime}$ value indicated a high gene expression level and vice versa (Kliem et al. 2009). The changes in mRNA expression of examined factors were assayed by normalisation to the UBQ internal control. The specificity of the desired products in bovine $\mathrm{CL}$ was documented using a highresolution gel electrophoresis and analysis of the melting temperature, which was product specific. 
Table 2 Primer sequences of FGF1, FGF2, FGF7, FGFR1IIIC, FGFR2IIIC, FGFR2IIIb, FSHR, LHR, CYP19A1 and housekeeping gene ubiquitin (UBQ), RT-PCR product length and reference of the investigated factors or of the according accession number in the EMBL database.

\begin{tabular}{|c|c|c|c|}
\hline Target & Sequence of nucleotide ${ }^{a}$ & Fragment size (bp) & $\mathrm{EMBL}^{\mathrm{b}}$ \\
\hline$F G F 1$ & For: $5^{\prime}$-CCAGGAAATTACAAGAAGCCC-3' & 264 & $X 60317$ \\
\hline FGF2 & $\begin{array}{l}\text { For: 5'-TCAAAGGAGTGTGTGCGAAC-3' } \\
\text { Rev: } 5^{\prime} \text {-CAGGGCCACATACCAACTG-3' }\end{array}$ & 161 & AJ577089 \\
\hline$F G F 7$ & $\begin{array}{l}\text { For: } 5^{\prime} \text {-CTGCCAAGTTTGCTCTACAG-3' } \\
\text { Rev: } 5^{\prime} \text {-TCCAACTGCCAGGGTCCTGAT-3' }\end{array}$ & 291 & AJ245447 \\
\hline FGFR1IIIC & $\begin{array}{l}\text { For: 5'-ACTGCTGGAGTTAATACCACCG-3' } \\
\text { Rev: 5'-GCAGAGTGATGGGAGAGTCC-3' }\end{array}$ & 125 & AJ577088 \\
\hline FGFR2IIIC & $\begin{array}{l}\text { For: 5'-CACCACGCCAAAGAGATTG-3' } \\
\text { Rev: } 5^{\prime} \text {-ATGGAGAGTGAAAGGATATCCC-3' }\end{array}$ & 113 & AJ439896 \\
\hline FGFR2IIIb & $\begin{array}{l}\text { For: 5'-TGGAGAATGAATACGGGTCC-3' } \\
\text { Rev: } 5^{\prime} \text {-TCGGTCACAATTGAACAGAGC-3' }\end{array}$ & 289 & AJ439895 \\
\hline$L H R$ & $\begin{array}{l}\text { For: 5'-GGAAATGGATTTGAAGAAATACAA-3' } \\
\text { Rev: } 5^{\prime} \text {-GTGCTTTCACATTGTTTGGAAAAG-3' }\end{array}$ & 376 & M29525 \\
\hline FSHR & $\begin{array}{l}\text { For: 5'-AAGCTTGTCGCCCTCATG-3' } \\
\text { Rev: 5'-CATTGTCTTCTGCCAGAGAGG-3' }\end{array}$ & 178 & AF025377 \\
\hline CYP19A1 & $\begin{array}{l}\text { For: 5'-CATCATGCTGGACACCTCTAAC-3' } \\
\text { Rev: } 5^{\prime} \text {-ATGTCTCTTTCACCAACAACAGTC-3' }\end{array}$ & 476 & U92245 \\
\hline$U B Q$ & $\begin{array}{l}\text { For: 5'-AGATCCAGGATAAGGAAGGCAT-3' } \\
\text { Rev: } 5^{\prime} \text {-GCTCCACCTCCAGGGTGAT-3' }\end{array}$ & 198 & ZI18245 \\
\hline
\end{tabular}

${ }^{\mathrm{a}}$ For, forwards; Rev, reverse. ${ }^{\mathrm{b}} \mathrm{EMBL}$ accession number of sequence.

\section{EIA for FGF2 determination in follicle, $C L$ and stroma tissue}

After extraction of tissue, the FGF2 concentration was tested by a commercial provided ELISA kit (Duo Set human FGF2, R\&D Systems, Inc., Minneapolis, MN, USA) according to the instructions of the manufacturer. The assay cross reacts with recombinant bovine FGF2. The range of the standard curve was 10-640 pg/ml.

\section{Immunohistochemistry of FGF2}

Ovarian tissue was fixed via immersion with methanol/glacial acid 2/1 v/v and Bouin's solution for FGF2, dehydrated after fixation in a series of graded ethanols, cleared in xylene and embedded in paraffin wax using conventional procedures as described previously (Steffl et al. 2004). Serial sections of $5 \mu \mathrm{m}$ thickness were cut from paraffin blocks on a Leitz microtome and collected on gelatine chromalaun-coated slides. Following deparaffinisation, the presence of FGF2 was demonstrated immunohistochemically by a streptavidin-biotin-HRP complex (ABC) method (Hsu et al. 1981). Potentially, endogenous peroxidase activity was eliminated by incubation with $0.5 \%(\mathrm{v} / \mathrm{v})$ hydrogen peroxide solution in absolute methanol for $15 \mathrm{~min}$, and non-specific protein binding was blocked by incubation with $10 \%$ normal goat serum in PBS for $1 \mathrm{~h}$ at room temperature. Sections were incubated overnight at $4{ }^{\circ} \mathrm{C}$ with 1:1200 dilution of rabbit anti-FGF2 (polyclonal antibody \#14, prepared in our laboratory and raised against recombinant bovine FGF2 (rbFGF2)). After washing in PBS, the sections were incubated for $30 \mathrm{~min}$ with biotinylated goat antirabbit IgG. The sections were then treated with $A B C$ reagent from a commercial kit (Vector Laboratories, Burlingame, CA, USA). The bound complex was visualised by incubation with $0.05 \% \quad 3,3^{\prime}$-diaminobenzidine tetrahydrochloride and
$0.0006 \%$ hydrogen peroxide in $0.1 \mathrm{~mol} / \mathrm{l}$ PBS. Between each step, sections were washed thrice in PBS. All incubations were carried out in humidified chambers to prevent drying out. Sections were counterstained with Mayer's haematoxylin, dehydrated, cleared and mounted.

The specificity of the immunohistochemical reactions was assessed by: i) replacement of the primary antibody with buffer, ii) its substitution with non-immune rabbit IgG (1:10 diluted), iii) incubation with diaminobenzidine reagent alone to exclude the possibility of non-suppressed endogenous peroxidase activity and iv) an absorption test involving the respective antigen $(15 \mathrm{mg} / \mathrm{ml})$. Lack of detected staining of tissue elements in the controls demonstrated the specificity of the reactions.

\section{Western blot}

Western blotting of FGF2 SDS-PAGE was performed according to the method described by Laemmli (1970). Samples (50 $\mu \mathrm{g}$ total protein in $20 \mathrm{ml}$ buffer) were boiled in NuPAGE SDS sample buffer (Novex, San Diego, CA, USA) for 5 min at $95{ }^{\circ} \mathrm{C}$ and separated on a commercially available $12 \%$ Bis-Tris gel (Invitrogen) under reducing conditions (for $1 \mathrm{~h}$ at $190 \mathrm{~V}$ ), and transferred to nitrocellulose membranes (Millipore PVDF, $0.45 \mathrm{~mm}$; Millipore, Bedford, MA, USA). For blocking, membranes were incubated in PBS with $0.05 \%$ Tween-20 (PBS-T) with $1 \%$ non-fat dry milk overnight. The membranes were then incubated in PBS-T and incubated for 75 min with the respective primary antibody for FGF2. The same antibody was utilised as used for immunohistochemistry. For immunoblot analysis, the antiserum was diluted 1:40 000 and detected by using goat anti-rabbit IgG peroxidase conjugate in combination with an ECL system (Amersham-Pharmacia). Negative controls were set up to replace the primary antibody with PBS. Protein samples from bovine CL or rbFGF2 (a kind 
gift from Dr D Gospodarowicz, Chiron Corp., Berkeley, CA, USA) was used as a positive control. Specificity of bands was tested by using preabsorbed antiserum involving the respective antigen. The See Blue Plus2 Pre-Stained standard (Novex) was used as a molecular size marker.

\section{Statistical analyses}

The statistical significance of differences in mRNA expression of examined factors and the concentrations of PGF2 $\alpha$ and steroids ( $E_{2}$ and $\left.P 4\right)$ were analysed by ANOVA followed by the Holm Sidak as a multiple comparison test. Data that failed the normality or equal variance test were tested by one-way ANOVA on ranks followed by the Kruskal-Wallis test (Sigma Stat 3.0). All experimental data were shown as mean \pm S.E.M. Differences were considered significant if $P<0.05$.

\section{Declaration of interest}

The authors declare that there is no conflict of interest that could be perceived as prejudicing the impartiality of the research reported.

\section{Funding}

This work was supported by the German Research Foundation (DFG).

\section{Acknowledgements}

The authors thank Dr D Gospodarowicz, Chiron Corp., Berkeley, CA, USA, for the supply of bovine FGF2 and Dr R Claus, University of Hohenheim for the supply of the PGF2 $\alpha$ antiserum. The authors are grateful to Mrs G Schwentker and Mrs K Müller for their technical assistance.

\section{References}

Acosta TJ, Berisha B, Ozawa T, Sato K, Schams D \& Miyamoto A 1999 Evidence for a local endothelin-angiotensin-atrial natriuretic peptide system in bovine mature follicles in vitro: effects on steroid hormones and prostaglandin secretion. Biology of Reproduction 61 1419-1425.

Ainsworth L, Tsang BK, Downey BR, Marcus GJ \& Armstrong DT 1980 Interrelationships between follicular fluid steroid levels, gonadotropic stimuli, and oocyte maturation during preovulatory development of porcine follicles. Biology of Reproduction 23 621-627.

Ainsworth L, Tsang BK, Downey BR \& Marcus GJ 1990 The synthesis and actions of steroids and prostaglandins during follicular maturation in the pig. Journal of Reproduction and Fertility 40 137-150.

Babalola GO \& Shapiro BH 1988 Correlation of follicular steroid hormone profiles with ovarian cyclicity in sows. Journal of Reproduction and Fertility 84 79-87.

Berisha B, Schams D, Kosmann M, Amselgruber W \& Einspanier R 2000a Expression and localization of vascular endothelial growth factor (VEGF) and basic fibroblast growth factor (FGF-2) during the final growth of bovine ovarian follicles. Journal of Endocrinology 167 371-382.

Berisha B, Schams D, Kosmann M, Amselgruber W \& Einspanier R 2000b Expression and tissue concentration of vascular endothelial growth factor, its receptors, and localization in the bovine corpus luteum during estrous cycle and pregnancy. Biology of Reproduction 63 1106-1114.
Berisha B, Sinowatz F \& Schams D 2004 Expression and localization of fibroblast growth factor (FGF) family members during the final growth of bovine ovarian follicles. Molecular Reproduction and Development 67 162-171.

Berisha B, Steffl M, Amselgruber W \& Schams D 2006a Changes in fibroblast growth factor 2 and its receptors in bovine follicles before and after $\mathrm{GnRH}$ application and after ovulation. Reproduction 131 319-329.

Berisha B, Welter H, Shimizu T, Miyamoto A, Meyer HHD \& Schams D $2006 b$ Expression of fibroblast growth factor 1 (FGF1) and FGF7 in mature follicles during the periovulatory period after $\mathrm{GnRH}$ in the cow. Journal of Reproduction and Development 52 307-313.

Cardenas H \& Pope WF 2002 Androgen receptor and follicle-stimulating hormone receptor in the pig ovary during the follicular phase of the estrous cycle. Molecular Reproduction and Development 62 92-98.

Chomczynski P \& Sacchi N 1987 Single-step method of RNA isolation by acid guanidinium thiocyanate-phenol-chloroform extraction. Analytical Biochemistry 162 156-159.

Corbin CJ, Moran FM, Vidal JD, Ford JJ, Wise T, Mapes SM, Njar VC, Brodie AM \& Conley AJ 2003 Biochemical assessment of limits to estrogen synthesis in porcine follicles. Biology of Reproduction 69 390-397.

Gabler C, Plath-Gabler A, Killian GJ, Berisha B \& Schams D 2004 Expression pattern of fibroblast growth factor (FGF) and vascular endothelial growth factor (VEGF) system members in bovine corpus luteum endothelial cells during treatment with FGF-2, VEGF or oestradiol. Reproduction in Domestic Animals 39 321-327.

Garrett WM \& Guthrie HD 1997 Steroidogenic enzyme expression during preovulatory follicle maturation in pigs. Biology of Reproduction $\mathbf{5 6}$ 1424-1431.

Gospodarowicz D, Cheng J, Lui GM, Baird A, Esch F \& Bohlen P 1985 Corpus luteum angiogenic factor is related to fibroblast growth factor. Endocrinology 117 2383-2391.

Gospodarowicz D, Ferrara N, Schweigerer L \& Neufeld G 1987 Structural characterization and biological functions of fibroblast growth factor. Endocrine Reviews 8 95-114.

Grant SA, Hunter MG \& Foxcroft GR 1989 Morphological and biochemical characteristics during ovarian follicular development in the pig. Journal of Reproduction and Fertility 86 171-183.

Guthrie HD, Barber JA, Leighton JK \& Hammond JM 1994 Steroidogenic cytochrome P450 enzyme messenger ribonucleic acids and follicular fluid steroids in individual follicles during preovulatory maturation in the pig. Biology of Reproduction 51 465-471.

Hsu SM, Raine L \& Fanger H 1981 Use of avidin-biotin-peroxidase (ABC) in immunoperoxidase techniques: a comparison between $A B C$ and unlabeled antibody (PAP) procedures. Journal of Histochemistry and Cytochemistry 29 577-580.

Hunter RH \& Poyser NL 1985 Ovarian follicular fluid concentrations of prostaglandins $E_{2}, F 2 \alpha$ and 12 during the pre-ovulatory period in pigs. Reproduction, Nutrition, Development 25 909-917.

Imamura T, Engleka K, Zhan X, Tokita Y, Forough R, Roeder D, Jackson A, Maier JAM, Hla T \& Maciag T 1990 Recovery of mitogenic activity of a growth factor mutant with a nuclear translocation sequence. Science $\mathbf{2 4 9}$ 1567-1570.

Johnson DE \& Williams LT 1993 Structural and functional diversity in the FGF receptor multigene family. Advances in Cancer Research 60 1-41.

Kliem H, Berisha B, Meyer HH \& Schams D 2009 Regulatory changes of apoptotic factors in the bovine corpus luteum after induced luteolysis. Molecular Reproduction and Development 76 220-230.

Laemmli UK 1970 Cleavage of structural proteins during the assembly of the head of bacteriophage T4. Nature 227 680-685.

Leiser R, Zimmermann W, Sidler X \& Christen A 1988 Normal cyclical morphology of the endometrium and ovary of swine. Tierärztliche Praxis $16261-280$.

Liu J, Aronow BJ, Witte DP, Pope WF \& La Barbera AR 1998 Cyclic and maturation-dependent regulation of follicle-stimulating hormone receptor and luteinizing hormone receptor messenger ribonucleic acid expression in the porcine ovary. Biology of Reproduction 58 648-658.

Livak KJ \& Schmittgen TD 2001 Analysis of relative gene expression data using real-time quantitative PCR and the 2 (-Delta Delta $C(T)$ ) method. Methods 25 402-408. 
Meyer HHD, Sauerwein H \& Mutayoba BM 1990 Immunoaffinity chromatography and a biotin-streptavidin amplified enzyme immunoassay for sensitive and specific estimation of estradiol-17b. Journal of Steroid Biochemistry and Molecular Biology 35 263-269.

Parrott JA \& Skinner MK 1998 Developmental and hormonal regulation of keratinocyte growth factor expression and action in the ovarian follicle. Endocrinology 139 228-235.

Parrott JA, Vigne JL, Chu BZ \& Skinner MK 1994 Mesenchymal-epithelial interactions in the ovarian follicle involve keratinocyte and hepatocyte growth factor production by thecal cells and their action on granulosa cells. Endocrinology 135 569-575.

Pepper MS \& Mandriota SJ 1998 Regulation of vascular endothelial growth factor receptor-2 (Flk-1) expression in vascular endothelial cells. Experimental Cell Research 241 414-425.

Pepper MS, Ferrara N, Orci L \& Montesano R 1992 Potent synergism between vascular endothelial growth factor and basic fibroblast growth factor in the induction of angiogenesis in vitro. Biochemical and Biophysical Research Communications 189 824-831.

Schams D \& Berisha B 2004 Regulation of corpus luteum function in cattle an overview. Reproduction in Domestic Animals 39 241-251.

Schams D, Amselgruber W, Einspanier R, Sinowatz F \& Gospodarowicz D 1994 Localization and tissue concentration of basic fibroblast growth factor in the bovine corpus luteum. Endocrine 2 907-912.

Seghezzi G, Patel S, Ren CJ, Gualandris A, Pintucci G, Robbins ES, Shapiro RL, Galloway AC, Rifkin DB \& Mignatti P 1998 Fibroblast growth factor-2 (FGF-2) induces vascular endothelial growth factor (VEGF) expression in the endothelial cells of forming capillaries: an autocrine mechanism contributing to angiogenesis. Journal of Cell Biology 141 1659-1673.

Sinowatz F, Schams D, Habermann F, Berisha B \& Vermehren M 2006 Localization of fibroblast growth factor I (acid fibroblast growth factor) and its mRNA in the bovine mammary gland during mammogenesis, lactation and involution. Anatomia, Histologia, Embryologia 35 202-207.

Stauber DJ, DiGabriele AD \& Hendrickson WA 2000 Structural interactions of fibroblast growth factor receptor with its ligands. PNAS 97 49-54.

Steffl M, Schweiger M \& Amselgruber WM 2004 Oestrous cycleregulated expression of inositol 1,4,5-trisphosphate receptor type 2 in the pig ovary. Acta Histochemica 106 137-144.

Wiedlocha A, Falnes PO, Rapak A, Munoz R, Klingenberg O \& Olsnes S 1996 Stimulation of proliferation of a human osteosarcoma cell line by exogenous acidic fibroblast growth factor requires both activation of receptor tyrosine kinase and growth factor internalization. Molecular and Cellular Biology 16 270-280.

Yamashita H, Kamada D, Shirasuna K, Matsui M, Shimizu T, Kida K, Berisha B, Schams D \& Miyamoto A 2008 Effect of local neutralization of basic fibroblast growth factor or vascular endothelial growth factor by a specific antibody on the development of the corpus luteum in the cow. Molecular Reproduction and Development 75 1449-1456.

Zeleznik AJ, Schuler HM \& Reichert LE Jr 1981 Gonadotropin-binding sites in the rhesus monkey ovary: role of thevasculature in the selective distribution of human chorionic gonadotropin to the preovulatory follicle. Endocrinology 109 356-362.

Received 2 February 2009

First decision 2 March 2009

Revised manuscript received 16 April 2009

Accepted 20 April 2009 